\title{
Las paradojas de la revolución. Figuraciones del cuerpo en la prensa del PRT-ERP en la Argentina de los años setenta
}

\author{
The paradoxes of revolution. Body figures in the PRT-ERP press in Argentina \\ during the $1970 \mathrm{~s}$
}

Mariela Peller*

\begin{abstract}
Resumen: "Poner el cuerpo" fue una frase que circuló entre la izquierda armada de los años setenta en Argentina, para referirse a la entrega de los sujetos a la revolución. ¿Pero de qué cuerpos se trataba? Desde la perspectiva teórico-metodológica de la historiadora feminista Joan Scott, el artículo realiza una relectura de la prensa del PRT-ERP para comprender las formas en que las representaciones corporales aparecieron en las revistas de modo paradojal. Si bien la agrupación registró la diferencia sexual, no ahondó en un pensamiento alrededor de lo que implicaba dicha diferencia para los sujetos de la política revolucionaria.
\end{abstract}

Palabras clave: PRT-ERP, cuerpo, género, diferencia sexual, revolución

\begin{abstract}
Poner el cuerpo" was a sentence which circulated in the armed left of the 70s in Argentina, to refer to the dedicated of people to revolution. However, what kind of bodies were they? From Joan Scott's perspective, this article makes a rereading of the PRT-ERP press to understand the frames in which the body's representations appear there in a paradoxical way. It's argued that while the press recorded the sexual difference, it did not delve into a thought around what that difference implied for the subject of revolution.
\end{abstract}

Keywords: PRT-ERP, body, gender, sexual difference, revolution

\footnotetext{
* Argentina. Socióloga y Doctora en Ciencias Sociales por la Universidad de Buenos Aires. Investigadora Asistente del CONICET con sede en el Instituto Interdisciplinario de Estudios de Género (FFyL-UBA) y docente en la Carrera de Sociología (FCS-UBA). Este artículo es una reelaboración de parte de mi tesis doctoral "Vida cotidiana, familia y revolución: la militancia en el PRT-ERP en la Argentina de los años sesenta y setenta", Universidad de Buenos Aires: Buenos Aires. 2014, que fue financiada por una beca doctoral el CONICET. mariela_peller@hotmail.com
} 


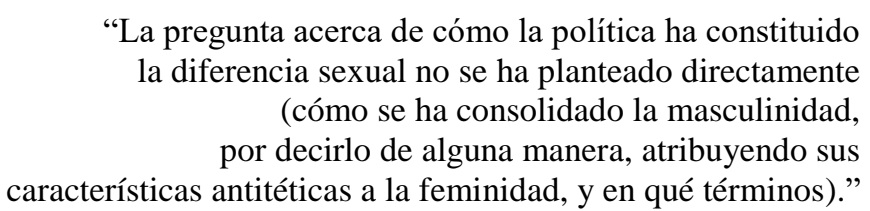

Joan W. Scott ${ }^{1}$

\section{Introducción}

"Poner el cuerpo" fue una frase que circuló entre la izquierda armada en la Argentina de los años setenta para referirse a la entrega que los sujetos hacían - de su tiempo, de su vida, de su trabajo- a los fines de la lucha revolucionaria. Asimismo, solía alabarse como figura ideal del militante a aquél que se entregaba "en cuerpo y alma" a la revolución. Estas afirmaciones se conforman sobre algunos supuestos que, desde la perspectiva que presento en este artículo, solicitan ser interrogados. Porque si los cuerpos se constituyeron en una de las figuras protagonistas de los discursos elaborados por la izquierda armada en general y por el PRT-ERP en particular, cabe preguntarse cuáles fueron esos cuerpos que aparecieron en el centro de la escena política: ¿de qué cuerpos se trataba?

En este artículo examino los modos de aparición, representación e imaginación de los cuerpos en la prensa del PRT-ERP porque considero que dicha dimensión resulta central para comprender a la izquierda armada, a su proyecto político y a los sujetos que estaban implicados en él. A lo largo de este estudio trataré de demostrar que la centralidad dada a los cuerpos fue un efecto secundario del modo en que el PRT-ERP entendió la lucha revolucionaria y no una concepción explícitamente elaborada. Asimismo, sostendré que las publicaciones de la prensa partidaria registraron la diferencia sexual, si bien no elaboraron un pensamiento articulado sobre lo que implicaba dicha diferencia para el sujeto de la política revolucionaria.

La militancia armada de los años sesenta y setenta en Argentina tuvo lugar en el marco de un movimiento más amplio de activación política, social y cultural, que se venía incrementando desde la segunda mitad de los años cincuenta. Desde mediados de aquella época la sociedad argentina vivía un proceso de creciente conflictividad social y política signado por la superposición y convergencia de diferentes tipos de crisis: económica, del sistema político, del régimen de acumulación y del Estado. ${ }^{2}$ Desde el derrocamiento del gobierno de Perón en 1955, se sucedieron gobiernos civiles y militares que no lograron imponer un proyecto de largo plazo. Las constantes intervenciones militares desembocaron

\footnotetext{
${ }^{1}$ Scott, Joan W., Género e historia, México, Fondo de Cultura Económica, 2008, 256.

${ }^{2}$ Pucciarelli, Alfredo (Ed.), La primacía de la política. Lanusse, Perón y la Nueva Izquierda en tiempos del GAN, Buenos Aires, Eudeba, 1999.
} 
en 1966 en el golpe de Estado del General Juan Carlos Onganía, mediante el cual las Fuerzas Armadas pretendían imponer su propio proyecto político, económico y social.

Como resultado de la persistencia de estas crisis se produjeron transformaciones significativas en las orientaciones y prácticas políticas de los actores sociales existentes, a la vez que emergieron organizaciones nuevas. Estas nuevas fuerzas sociales, que han sido denominadas como Nueva Izquierda, si bien no lograron constituirse en un actor político unificado, alimentaron un potente proceso de contestación social y política, que comenzó a ser clausurado con el retorno del peronismo al poder y, más particularmente, con el golpe de Estado de $1976 .{ }^{3}$ Las organizaciones armadas de la izquierda surgen en ese marco y se presentan como un modo de respuesta a la violencia impuesta por años por regímenes autoritarios. ${ }^{4}$ Haciendo suya una idea cada vez más extendida en la izquierda nacional e internacional, las organizaciones guerrilleras privilegiaban la lucha armada y sostenían una concepción de la violencia como elemento central de cambio revolucionario de las estructuras políticas, sociales y económicas.

Estas transformaciones de la sociedad argentina no se desarrollaron sólo en los espacios de vanguardia -sean estéticos, políticos o culturales- sino que también se sucedieron en la vida cotidiana, las relaciones de género, la sexualidad y los vínculos intergeneracionales, siendo las mujeres y los jóvenes los dos grupos más fuertemente implicados. En aquellos años, muchas pautas sexuales, familiares y de género se reorganizaron y comenzaron a difundirse en Argentina ideas provenientes del feminismo, junto con la píldora anticonceptiva y la revolución sexual. Las mujeres expandieron su educación y su participación en el mercado de trabajo, al tiempo que el modelo femenino de la domesticidad, en el cual la mujer era la encargada del hogar y el marido el sostén económico, comenzó a verse resquebrajado. Las mujeres ahora querían trabajar, estudiar, ser independientes económicamente y sexualmente activas. ${ }^{5}$

En ese marco de renovaciones culturales y sociales, en 1965 surge el Partido Revolucionario de los Trabajadores (PRT). El grupo se conforma mediante la unión entre el Frente Revolucionario Indoamericano Popular, un grupo indigenista de Santiago del Estero liderado por Mario Roberto Santucho, y Palabra Obrera, una organización trotskista liderada por Nahuel Moreno. ${ }^{6}$ Desde su fusión se presentaron diferencias entre ambos sectores, hasta que en 1968 la ruptura se precipitó en torno al tema específico de la lucha armada. El grupo liderado por Santucho creía necesario iniciar inmediatamente las actividades militares, es así que dos años más tarde, en el V Congreso de julio de 1970, en

\footnotetext{
${ }^{3}$ Tortti, María Cristina, "Protesta social y "Nueva Izquierda" en la Argentina del "Gran Acuerdo Nacional", en Pozzi, Pablo y Schneider, Alejandro (comp.). Los setentistas. Izquierda y clase obrera: 1969- 1976, Buenos Aires, Eudeba, 2002.

${ }^{4}$ Calveiro, Pilar, Política y/o violencia. Una aproximación a la guerrilla de los años 70, Buenos Aires, Norma, 2005.

${ }^{5}$ Sobre las modificaciones en la vida de las mujeres y las pautas de género durante los años sesenta y setenta son imprescindibles los trabajos de Feijoó, María del Carmen; Nari, Marcela, "Women in Argentina during the 1960s", Latin American Perspectives, 23:1, California, 1996; Nari, Marcela, "Abrir los ojos, abrir la cabeza: el feminismo en la Argentina de los años '70", Feminaria, IX: 18/19, Buenos Aires, 1998; Barrancos, Dora. Mujeres en la sociedad argentina. Una historia de cinco siglos, Buenos Aires, Sudamericana, 2007; y Cosse, Isabella, Pareja, sexualidad y familia en los años sesenta, Buenos Aires, Siglo XXI, 2010.

${ }^{6}$ Para una historia del PRT-ERP se puede consultar: Pozzi, Pablo, 'Por las sendas argentinas...' El PRTERP, la guerrilla marxista, Buenos Aires, Imago Mundi, 2004.
} 
el que ya no participarían ni el sector ligado a Moreno ni las fracciones que se oponían al ritmo de la militarización, se funda el Ejército Revolucionario del Pueblo (ERP). ${ }^{7}$ El PRTERP fue uno de los grupos armados más significativos de la época, cuya importancia deriva de su influencia política en amplios sectores sociales, su vasta capacidad militar y de su alcance nacional. ${ }^{8}$

\section{Género, diferencia sexual y revolución: una relectura}

En los últimos años, las ciencias sociales y la historiografía en Argentina (y en otros países del Cono Sur) se están dedicando al estudio de las transformaciones ocurridas en los campos de la sexualidad, la familia y las relaciones de género en las décadas del sesenta y setenta. A grandes rasgos, se pueden distinguir dos grupos de investigaciones, que si bien trabajan desde una común perspectiva de género difieren a nivel temático. Un primer grupo aborda problemáticas referidas a los cambios en la vida privada y personal de las mujeres y los varones en la década del sesenta, comparando los nuevos modelos familiares, juveniles y sexuales con los vigentes en la década anterior. ${ }^{9}$ Un segundo grupo analiza la militancia de las mujeres y las relaciones de género en las organizaciones guerrilleras en particular, cotejando los mandatos partidarios con las experiencias de militancia, principalmente en lo relativo a los roles de género. ${ }^{10}$ Este segundo grupo de estudios sobre el pasado reciente, que incorpora reflexiones teórico-metodológicas del feminismo y de los estudios de género, han sido de suma importancia para generar una apertura respecto de las preguntas posibles de realizar cuando se estudian las organizaciones revolucionarias. Estos trabajos previos hicieron evidente que era factible y determinante para comprender el funcionamiento de las organizaciones armadas, interesarse por cuestiones relativas a la vida cotidiana, las

\footnotetext{
${ }^{7}$ Para una comprensión de las discusiones al interior del PRT-ERP se puede consultar el libro de Vera Carnovale, Los combatientes: historia del PRT-ERP, Buenos Aires, Siglo XXI, 2011

${ }^{8}$ Weisz, Eduardo, El PRT-ERP: Nueva Izquierda e izquierda Tradicional, Buenos Aires, Ediciones del Instituto Movilizador de Fondos Cooperativos, 2004.

${ }^{9}$ Entre los trabajos que refieren a las pautas familiares, culturales y sexuales se deben mencionar Cosse, Isabella, Felitti, Karina y Manzano, Valeria (ed.), Los '60 de otra manera. Vida cotidiana, género y sexualidades en la Argentina, Buenos Aires, Prometeo, 2010; Cosse, Isabella, op. cit.; Karina Felitti, La revolución de la píldora. Sexualidad y política en los sesenta, Buenos Aires, Edhasa, 2012.

${ }^{10}$ Entre los trabajos previos que estudian cuestiones de género en la militancia en organizaciones de la izquierda armada se encuentran: Andújar, Andrea, D’Antonio, Débora, Gil Lozano, Fernanda; Gramático, Karin, y Rosa, María Laura (comp.), De minifaldas, militancias y revoluciones. Exploraciones sobre los 70 en Argentina, Buenos Aires, Luxemburg, 2009; Grammático, Karin: Mujeres montoneras. Una historia de la Agrupación Evita, 1973-1974, Buenos Aires, Luxemburg, 2011; Martinez, Paola, Género, política y revolución en los años setenta. Las mujeres del PRT-ERP, Buenos Aires, Imago Mundi, 2009; Peller, Mariela, "Vida cotidiana y militancia armada en los años "70 en la Argentina: problemas conceptuales e hipótesis de lectura", INTERthesis, 10: 1, Santa Catarina, 2013; Peller, Mariela, Vida cotidiana, familia y revolución: la militancia en el PRT-ERP en la Argentina de los años sesenta y setenta, Tesis de Doctorado, Universidad de Buenos Aires, Buenos Aires, 2014; Oberti, Alejandra, Las revolucionarias, Buenos Aires, Edhasa, 2015; Cosse, Isabella, "Infidelidades: moral, revolución y sexualidad en las organizaciones de la izquierda armada en la Argentina de los años 70", Prácticas de oficio, 1: 19, San Miguel, 2017; Cosse, Isabella, "Militancia, sexualidad y erotismo en la izquierda armada de los años 70", en Dora Barrancos, Donna Guy, Adriana Valobra (ed.), Moralidades y comportamientos sexuales: Argentina, 1880-2011, Buenos Aires, Biblos, 2014.
} 
relaciones afectivas, los vínculos personales, las relaciones de género y la sexualidad. ${ }^{11}$ Estas investigaciones permitieron hacer visible que para entender las ideas y las prácticas de la izquierda armada no alcanzaba con un análisis de sus estrategias, prácticas y nociones relativas a la violencia política y al funcionamiento en el campo de lo militar. ${ }^{12}$

A partir de las aperturas realizadas por las investigaciones previas, en este artículo me propongo complejizar el análisis desde ciertos ejes teórico-metodológicos presentes en la perspectiva de la historiadora feminista Joan Scott, principalmente en su libro Las mujeres y los derechos del hombre, en el cual reflexiona sobre la noción de paradoja. En este estudio realizo una "relectura" de los discursos presentes en la prensa del PRT-ERP, en los términos en los que la entiende Scott. Una relectura, para esta autora, supondría leer los textos y las imágenes de la prensa buscando las paradojas y contradicciones, eludiendo la conformación de narrativas en términos evolucionistas, que impliquen un progreso acumulativo. Lo que se busca, por el contrario, es atender a los conflictos, las persistencias y las obsesiones de los discursos de prensa del PRT-ERP, para identificar aquello que se repite, que permanece inalterable a pesar de los supuestos intentos -enunciados en algunos de los propios escritos del partido- por establecer una igualdad entre los géneros al interior de la militancia. ${ }^{13} \mathrm{Mi}$ perspectiva retoma asimismo las reflexiones elaboradas por Alejandra Oberti en su libro Las revolucionarias. Allí, la autora propone la noción de "lectura desde el género", que retoma de los análisis de la crítica literaria Sylvia Molloy. Oberti sostiene que en su trabajo se trataría entonces de realizar "lecturas desde el género y no en y sobre el género". ${ }^{14}$ Una lectura desde el género, en los términos de Oberti, habilitaría preguntas e interpretaciones que involucran no sólo un fuerte compromiso con la noción de género sino también con el lenguaje, su funcionamiento y sus efectos sobre los sujetos y las identidades. Entendidas en estos términos, la lectura (en los términos de Molloy y Oberti) o la relectura (en los términos de Scott) se tornan práctica teórica, metodológica y política.

En este artículo entenderé al género como un elemento constitutivo de todas las relaciones sociales -que incluye símbolos, normativas, nociones e identidades- y como un campo primario en el que se articula el poder, ejerciendo una función legitimadora y constituyéndose en un modo de decodificar significados sociales. En otras palabras, género sería un modo de conocimiento. De esta definición, que retomo del clásico texto de Joan Scott, deriva su utilidad para un estudio de las organizaciones armadas en general y del

\footnotetext{
${ }^{11}$ Entre los trabajos pertenecientes a otros países del Cono Sur se destacan para Brasil Pedro, Joana Maria, Scheibe Wolff, Cristina, y Veiga, Ana María (org.), Gênero, feminismos e ditaduras no cone sul, UFSC, 2010, y Resistências, gênero e feminismos contra as ditaduras no cone sul, UFSC, 2011. Para Chile se puede mencionar los trabajos de Javiera Robles Recabarren "Memorias de la clandestinidad: Relatos de la militancia femenina del Frente Patriótico Manuel Rodríguez", Revista Nomadías, 19, Santiago de Chile, 2015, y de Vidaurrázaga, Tamara, "La escisión entre lo individual y lo colectivo en la moral revolucionaria militante de la nueva izquierda", Revista Sujeto, Subjetividad y Cultura, 4, Santiago de Chile, 2012.

12 Asimismo, algunos textos compuestos por testimonios de mujeres (ex militantes o parejas de militantes) colaboraron en la apertura de preguntas sobre los vínculos entre vida cotidiana, sexualidad y política en las organizaciones revolucionarias. Me refiero a Mujeres guerrilleras de Marta Diana de 1996 y Pájaros sin luz de Noemí Ciollaro de 2000.

${ }^{13}$ Para trabajar las nociones de paradoja y relectura me baso en el libro Joan Wallach Scott, Las mujeres y los derechos del hombre, Buenos Aires, Siglo XXI, 2012, principalmente en el capítulo "Releer la historia del feminismo" (17-38).

${ }^{14}$ Oberti, op. cit., 26.
} 
PRT-ERP en particular. ${ }^{15} \mathrm{Mi}$ análisis no pretende describir los roles de género al interior de las organizaciones armadas ni entiende al género y a las definiciones de "hombre" y "mujer" como cuestiones inmutables a lo largo del tiempo. Tampoco supone la existencia previa de la diferencia sexual como si ésta fuera un hecho biológico sobre el cual se montan los rasgos culturales del género. Desde la perspectiva de Scott, que intento seguir aquí, las investigaciones que solamente atienden a los roles de género reforzarían la construcción ideológica de una noción de "hombre" como un ser únicamente racional y de una noción de política como una actividad de agentes únicamente racionales. ${ }^{16}$ Escribe Scott, sobre la utilidad de la categoría de género para los estudios históricos:

Con demasiada frecuencia, "género" connota un enfoque programático o metodológico en el cual los significados de "hombre" o "mujer" se toman como fijos; el objetivo parece ser describir roles diferentes, no cuestionarlos. Creo que género sigue siendo útil sólo si va más allá de este enfoque, si se toma como una invitación a pensar de manera crítica sobre cómo los significados de los cuerpos sexuados se producen en relación uno con el otro, y cómo estos significados se despliegan y cambian. El énfasis debería ponerse no en los roles asignados a las mujeres y a los hombres, sino a la construcción de la diferencia sexual en sí. ${ }^{17}$

Esta perspectiva teórica posibilita la aparición de ciertas preguntas que intentaré responder en este trabajo: ¿qué relación entre género y política construían las imágenes presentes en la prensa? ¿Cómo se concebía la diferencia sexual y de qué modos apelaban a dicha diferencia? ¿Qué significados sobre "mujer” y "hombre” se elaboraron? ¿Qué valores psíquicos y corporales se invocaban respecto de las diferencias sexuales? ¿Cómo podían aparecer las mujeres en los discursos? Estas preguntas permiten "renunciar a evaluaciones simples sobre la posición de las mujeres en términos de progreso y retroceso", ${ }^{18}$ para en cambio atender a la presencia de paradojas. Un análisis de este tipo permitirá comprender el modo en que -y esta es mi hipótesis- las representaciones y figuraciones de los cuerpos en la prensa partidaria del PRT-ERP se configuraron de un modo paradojal. Los discursos presentes en la prensa, mientras, en algunos casos, suprimían el género, construyendo una figura de revolucionario que portaba los caracteres de la masculinidad y la virilidad -el "hombre nuevo"- y en otros hablaban de una supuesta igualdad entre los géneros, no hacían otra cosa que producir la diferencia sexual. De esta manera, se puede sostener que las mujeres fueron subsumidas en la categoría neutra y masculina del militante, si bien hubo ciertos desplazamientos, por ejemplo, en los casos en que ellas pudieron tener una voz propia. Dicha subsunción no hacía más que insistir en la diferencia sexual y, de esa manera, producirla como efecto de los discursos. En otras palabras, los discursos mostraban cierta

\footnotetext{
${ }^{15}$ Scott, Joan Wallach, "El género: Una categoría útil para el análisis histórico", en María Celia Cangiano y Lindsay Dubois, De mujer a Género, teoría, interpretación y práctica feminista en las ciencias sociales, Buenos Aires, CEAL, 1996.

${ }^{16}$ Scott, Joan Wallach, Género e historia, op. cit., 247.

${ }^{17}$ Scott, Joan, “Género: ¿Todavía una categoría útil para el análisis?”, La manzana de la discordia, 2011, 6: 1, Cali, 98. En ese artículo Scott retoma la discusión planteada en su ya clásico trabajo "El género: Una categoría útil para el análisis histórico", op. cit.

${ }^{18}$ Scott, Joan, Género e historia, op. cit. 254.
} 
repetición respecto de la ideología de la política "burguesa" dentro de la cual parece haber seguido operando la izquierda.

En un texto en el que estudia la obra de Joan Scott, Judith Butler destaca que las tensiones, contradicciones y obsesiones que Scott ha encontrado en diversos trabajos sobre los discursos vinculados al feminismo y a la política refieren de modo general a "una cierta condición paradójica de la política". ${ }^{19} \mathrm{La}$ política feminista es paradojal porque para protestar en contra de la exclusión de las mujeres de la política, necesita insistir en la identidad "mujeres" y hacer reclamos en su nombre. Esto implica que, para defender la igualdad entre los hombres y las mujeres, debe crear el sujeto ("las mujeres") que en realidad desea eliminar. De esta manera, dice Butler, es necesario al mismo tiempo refutar y aceptar la diferencia sexual. La política del PRT-ERP, al menos en lo referido al análisis de las publicaciones de prensa, se mostró paradójica en ese mismo sentido. Porque si las figuras del militante y del "hombre nuevo" pretendían presentarse como recursos igualadores (tal como Scott explica que funcionó la idea de Derechos del Hombre y el Ciudadano), ese discurso de la igualdad no hacía más que producir la diferencia sexual al querer ocultarla, argumentando una supuesta igualdad originaria entre varones y mujeres.

A partir de estas ideas sobre la condición paradójica de la política, en este artículo analizo las imágenes y los textos referidos a los cuerpos en la prensa partidaria del PRTERP. La agrupación tuvo dos periódicos clandestinos, un diario, un semanario y una revista, y también publicaciones dirigidas a espacios específicos de militancia, como gremios y sectores juveniles. En este artículo examino los dos órganos oficiales de prensa, El Combatiente (1968-1981) y Estrella Roja (1971-1977). ${ }^{20} \mathrm{Mi}$ estudio minucioso de la prensa me ha llevado a seleccionar artículos e imágenes por su carácter paradigmático respecto de las cuestiones que quiero analizar. He seleccionado para el análisis aquellos textos de la prensa que refieren de modos más o menos evidentes a las relaciones de género, las corporalidades, los valores vinculados a lo femenino y lo masculino, la división

\footnotetext{
${ }^{19}$ Butler, Judith, "Hablando claro, contestando. El feminismo crítico de Joan Scott", Rey desnudo, II: 4, Buenos Aires, 2014, 33.

${ }^{20}$ El Combatiente Órgano del Partido de los Trabajadores. Por la Revolución Obrera, Latinoamericana y Socialista se publicó semanalmente desde marzo de 1968 hasta diciembre de 1981, contando con 290 números publicados. Circuló en Córdoba, Rosario, Tucumán, Ciudad de Buenos Aires y Gran Buenos Aires. Algunas de las secciones de la publicación fueron: Lucha Ideológica, Economía, Línea del Partido, Vida y Organización Partidaria, Sindical, Internacional, Corresponsalías y Construcción del socialismo (referida a experiencias internacionales del socialismo). Asimismo, la revista reproducía las resoluciones de los Congresos del Partido y las reuniones del Comité Central y del Comité Ejecutivo. Por su parte, Estrella Roja Órgano del Ejército Revolucionario del Pueblo se publicó quincenalmente entre abril de 1971 y febrero de 1977, contando con 93 números. Algunas de las secciones recurrentes de la revista eran artículos dedicados a difundir el Programa del ERP, Crónica de la guerra revolucionaria, Fichas técnicas, Correspondencia de lectores, Relatos de la guerra revolucionaria, Comunicados de prensa, Necrológicas de las y los militantes asesinados y Justicia popular. Para más información sobre las publicaciones del PRT-ERP se puede consultar: De Santis, Daniel, A vencer o morir: PRT-ERP, Buenos Aires, Eudeba, 2000, 20. Para datos sobre la tirada de estas revistas en sus etapas de distribución legal y clandestina se puede consultar: Pozzi, op. cit, $187-188$.
} 
de tareas entre los sexos, entre otras cuestiones que permiten observar los modos en que el PRT-ERP concibió a las subjetividades políticas atravesadas por el género. ${ }^{21}$

El PRT incluyó entre las diversas tareas centrales del partido, designadas por el Comité Central, la propaganda de masas y la propaganda de vanguardia. El Combatiente era el órgano de prensa que se dirigía hacia los sectores de la vanguardia política, hacia quienes ya eran militantes al interior del partido, mientras que Estrella Roja, estaba dirigido a las masas, a un público más general, a un destinatario aún no comprometido con la causa revolucionaria, que requería un mayor nivel de persuasión. ${ }^{22}$ Como ha señalado Roger Chartier -y como demuestra también el interés del PRT en las tareas de propaganda política- lo escrito puesto a circular siempre ha sido fundamental para quienes pretenden reglamentar y moldear las conductas y las creencias de los sujetos. ${ }^{23}$ Poner discursos en circulación y lograr que otros los reciban es una tarea fundamental de cualquier partido político que quiere ampliar su campo de influencias. Jean-Marie Domenach ha estudiado las diversas formas en las que la propaganda política sugiere e impone creencias que a menudo logran modificar el comportamiento, el psiquismo y las convicciones de los sujetos. ${ }^{24}$ Sin dudas, quienes editaban las publicaciones del PRT-ERP sabían de los efectos que implicaba poner a circular discursos escritos entre los militantes y entre aquellos ciudadanos a quienes querían convocar hacia la causa revolucionaria.

En este artículo sostengo que los discursos de la prensa del PRT-ERP tuvieron un rol pedagógico, disciplinante y prescriptivo, puesto que actuaron imponiendo modelos sobre los cuerpos, las actitudes y las creencias de las y los militantes. Asimismo, actuaron persuasivamente sobre aquellos lectores a quienes se quería convocar a sumarse a la causa revolucionaria. Las figuras corporales presentes en la prensa funcionaron como normativas para la construcción de cuerpos apropiados para la lucha revolucionaria. Pusieron a circular estereotipos sobre lo masculino y lo femenino, y modelos ideales del militante revolucionario, que delimitaron roles y tareas. Al introducir argumentos sobre las diferencias entre las mujeres y los hombres, no hicieron otra cosa que conformar la diferencia sexual como un eje de su discurso político. Como intentaré mostrar en mi exposición esas configuraciones corporales estuvieron marcadas - de un modo paradójicopor la diferencia sexual, que emergió como un efecto y no como una causa de esos discursos que se pretendían igualitarios.

\section{Una pedagogía de guerra}

En el primer número de Estrella Roja, publicado en abril de 1971, los editores llamaban a "Formar comandos de apoyo al ERP". En cada fábrica, barrio, facultad, colegio y sin esperar el contacto con los combatientes "la consigna es: ORGANIZATE, COMBATE, ARMATE Y ESPERA. TODO EL PUEBLO, HOMBRE, MUJER, NIÑO,

\footnotetext{
${ }^{21}$ Todas las publicaciones de la prensa del PRT-ERP que se citan en el artículo pueden consultarse en el sitio web de El Topo Blindado. Centro de documentación de las organizaciones política-militares argentinas: www.topoblindado.com.

${ }^{22}$ PRT, “Las tareas centrales del partido”, El combatiente, 134, 1974, 7.

${ }^{23}$ Chartier, Roger, El mundo como representación. Estudios sobre historia cultural, Barcelona, Gedisa, 2005.

${ }^{24}$ Domenach, Jean-Marie, La propaganda política, Buenos Aires, Eudeba, 1993.
} 
TIENE SU LUGAR EN EL COMBATE". ${ }^{25}$ Esta consigna implicaba una clara incitación a la participación en la que a simple vista parecía no haber distinciones según la edad o el sexo de las personas: todos podían ocupar un lugar en el proceso revolucionario, convirtiéndose en combatientes. Era una consigna con intenciones inclusivas.

Si la convocatoria parecía no distinguir entre el pueblo, un hombre, una mujer o un niño, sino que, por el contrario, intentaba borrar esas divergencias mediante la construcción de un enunciador y un destinatario masculino universal, el análisis que presento a continuación muestra las operaciones discursivas mediante las cuales se fue fragmentando el territorio (material y simbólico) de la militancia, otorgando a cada uno tareas, roles y espacios diferenciados, según el género. En muchos casos, paradójicamente, fueron esas mismas operaciones que se presentaban como igualadoras las que generaron la diferenciación. $\mathrm{Si}$, por un lado, se llamaba a una multiplicidad de sujetos a sumarse a la causa revolucionaria, por el otro, las imágenes de la prensa devolvían más bien un sujeto único. Isabella Cosse ha analizado la figura que fue seleccionada para la portada de este primer número de Estrella Roja: un varón joven pero no adolescente, con la cara lampiña y el brazo en alto con un fusil. Cosse lee dicha figura como un símbolo de la "virilidad guerrillera", desafiante de la masculinidad doméstica, que estaba siendo criticada en esa época por los jóvenes de clase media. ${ }^{26}$

Como ha planteado Roberto Pittaluga, el PRT-ERP tendió a concebir a la revolución en términos de guerra. Si en un primer momento primaba una idea insurreccional de la revolución, a medida que la cuestión de la lucha armada apareció en escena, por medio de los modelos de la revolución cubana y vietnamita, el acento se fue desplazando desde la acción política hacia la acción la militar. Como resultado la revolución pasó a ser entendida en términos de guerra y los protagonistas del cambio dejaron de ser las masas para pasar a ser los combatientes. ${ }^{27}$

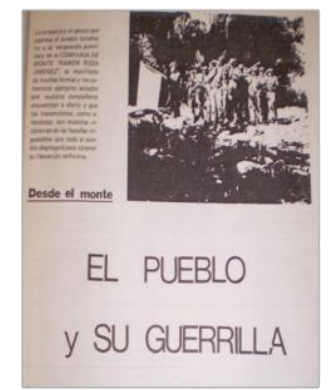

$$
\begin{gathered}
\text { Imagen 1 } \\
\text { "El pueblo y su guerrilla" } \\
\text { Estrella Roja, 44, 1974, } 3
\end{gathered}
$$

Esta concepción de la revolución en términos de guerra supuso unos modos específicos de imaginar y representar los cuerpos de los revolucionarios. En la prensa, los cuerpos de los revolucionarios se exhibían como cuerpos de combatientes y soldados integrantes de un ejército. Son cuerpos que cargan armas de fuego, que construyen y manipulan bombas, se trata de cuerpos capaces de exponerse hasta la muerte en un combate. Veamos algunos ejemplos referidos a la Compañía de Monte Ramón Rosa Jiménez, que funcionó en el sur de la provincia de Tucumán. ${ }^{28}$ En esos

\footnotetext{
${ }^{25}$ ERP, "Formar comandos de apoyo al ERP”, Estrella Roja, 1, abril 1971. Las mayúsculas están en el original.

${ }^{26}$ Isabella Cosse, "Militancia, sexualidad y erotismo en la izquierda", op. cit., 293-321.

${ }^{27}$ Roberto Pittaluga, "Nociones de la revolución en el PRT-ERP", ponencia presentada en las VIII Jornadas Interescuelas/Departamentos de Historia, Salta, Universidad Nacional de Salta, 2001.

${ }^{28}$ En el marco de su constitución como ejército guerrillero regular en 1974 el PRT- ERP conformó un frente militar en el sur de Tucumán. La mayoría de sus integrantes provenían del espacio urbano, sobre todo de la ciudad de Córdoba, muy pocos eran tucumanos y prácticamente ninguno conocía el monte. La Compañía fue desarticulada a mediados de 1975 en el denominado Operativo Independencia. Pozzi, op. cit. 265- 280.
} 
artículos, el cuerpo del militante aparece como el cuerpo de un soldado, conformado a través de la vestimenta de uniformes militares, de las posiciones corporales adoptadas y de la posesión de fusiles. En el artículo "Desde el monte. El pueblo y su guerrilla" (1974) se exhibe una fotografía de militantes con uniformes de soldados en fila, que cargan fusiles y portan una bandera en el entorno del monte tucumano (Imagen 1) ${ }^{29}$.

Diversos mandatos referidos a los cuerpos armados se pueden rastrear asimismo en la serie de artículos denominada "Ficha Técnica". Dichas fichas contienen indicaciones para utilizar armas, fabricar explosivos en casa, practicar puntería, construir granadas de mano, entre otros métodos para construir armas y explosivos de modo casero. Mediante un estilo discursivo didáctico las fichas dan indicaciones de los pasos a seguir, junto con dibujos y diagramas, conformando una pedagogía de guerra. Por ejemplo, la ficha “¿Cómo construir una molotov?" presenta los pasos a seguir para montar una bomba en casa (Imagen 2).

\section{Imagen 2 \\ “¿Cómo construir una Molotov?" \\ Estrella Roja, 8, 1971, 6-7}

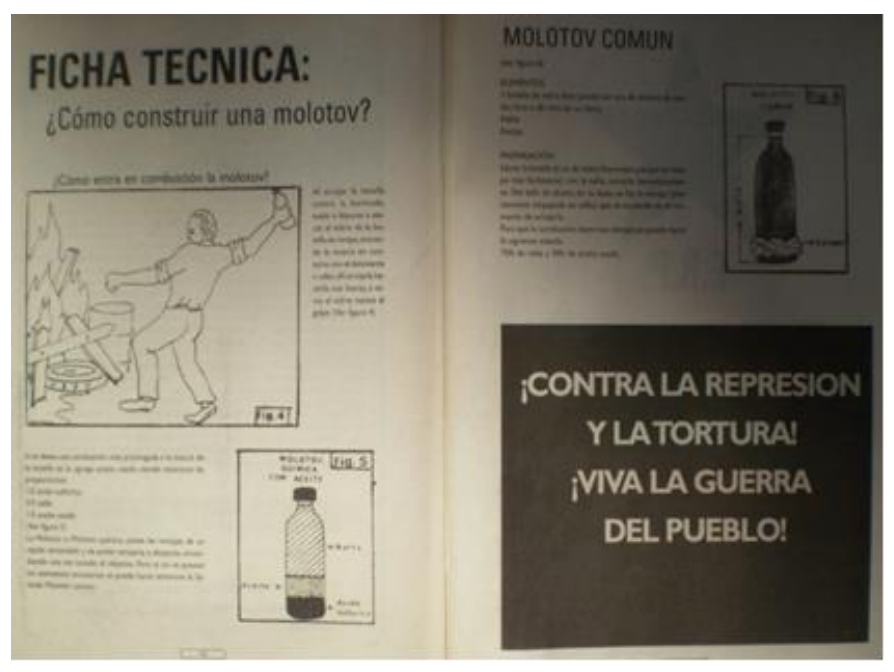

Los elementos necesarios son una botella de vidrio, nafta, estopa. La preparación: "Llenar la botella (si es de vidrio fino mejor, porque se rompe más fácilmente) con la nafta, cerrarla herméticamente. Del lado de afuera, en su base, se fija la estopa (previamente empapada en nafta) que se enciende en el momento de arrojarla". ${ }^{30}$ El registro infantilizado, que se ve reforzado por los dibujos realizados a mano, genera que un tema -política y éticamente- complejo como es construir y tomar un arma por parte de un sujeto, sea presentado con un tono de ligereza. Este estilo didáctico y la liviandad con la que se trata el tema tienen el efecto de desestimar la envergadura del hecho armado a la vez que parecen postular que cualquiera puede convertirse en un revolucionario. Cualquiera puede aprender

\footnotetext{
${ }^{29}$ ERP, "Desde el monte. El pueblo y su guerrilla", Estrella Roja, 44, 1974, 3. Ésta y las siguientes imágenes pueden verse en el anexo al final del artículo.

${ }^{30}$ ERP, “¿Cómo construir una Molotov?”, Estrella Roja, 8, 1971, 6-7.
} 
desde su casa lo necesario para ser un combatiente. En este tipo de artículo se puede observar cómo actúa la intención persuasiva de la prensa. Son artículos que no hacen otra cosa que intentar convocar a los ciudadanos a unirse a la causa de la revolución.

No se puede perder de vista, que la figura del cuerpo armado puede interpretarse más allá de la idea de estar provisto de armas. Armado también significa formado, creado, fraguado. Me interesa remarcar estos otros sentidos porque refieren a cierta confianza que tenía la agrupación en la posibilidad de construcción, adaptación y cambio de los cuerpos. Una confianza en la plasticidad de los sujetos que, si seguimos a Alain Badiou en su ensayo sobre el siglo XX, parece haber sido parte de un imaginario que excedía a la izquierda armada argentina y que puede rastrearse en los discursos revolucionarios de diversas latitudes a lo largo de todo el siglo. Según este autor la idea de cambiar al hombre, de crear un hombre nuevo, que implicaba, por supuesto, la destrucción del viejo, aparece como una de las "obsesiones" para el siglo XX. Escribe Badiou:

Crear un hombre nuevo equivale siempre a exigir la destrucción del viejo. La discusión, violenta e irreconciliable, se refiere a la definición del hombre antiguo. Pero en todos los casos el proyecto es tan radical que en su realización no importa la singularidad de las vidas humanas; ellas son un mero material. ${ }^{31}$

Como muestran las imágenes de la prensa, las construcciones y modificaciones corporales requeridas son presentadas como la consecuencia de la voluntad de unos sujetos que siguiendo los mandatos del partido deben transformar su corporalidad acomodándola a las necesidades de la revolución. Ese mandato de adaptación del cuerpo para la lucha recordemos que "poner el cuerpo" fue una consigna fundamental de la época- parece haber ubicado al sujeto en el centro de la escena política. Pero, paradójicamente, ese trabajo de moldura que cada militante debía realizar sobre su cuerpo no aparecía como un fin en sí mismo, sino que se presentaba como un medio necesario en el camino hacia la revolución. Como sostuvo tempranamente Héctor Schmucler, esta fragmentación entre medios y fines, donde el sujeto aparece como el medio de un fin revolucionario que está en otra parte, habría sido el corolario de un modo específico de entender la política. Una política entendida como técnica, como una parte de la vida cotidiana, como un campo diferenciado del quehacer humano, sería una política que continuaría enmarcada dentro de una concepción burguesa. ${ }^{32}$

Al entender la revolución en términos de guerra, el cuerpo del revolucionario se presentaba como un cuerpo de combatiente que debía portar los rasgos tradicionalmente asociados con la masculinidad y la virilidad. La conformación de una pedagogía de guerra da cuenta de una confianza en la plasticidad de los cuerpos, que parecía poner el cuerpo en el centro de la política. No obstante, esa importancia de los cuerpos fue paradojal, ya que al mismo tiempo que los colocaba como fundamentales para la revolución, los rechazaba como fines en sí mismos. Eran cuerpos para la revolución.

\footnotetext{
${ }^{31}$ Badiou, Alain, El siglo, Buenos Aires, Manantial, 2005, 20.

${ }^{32}$ Schmucler, Héctor, “Testimonio de los sobrevivientes", Controversia, 9-10, México, 1980.
} 


\section{"Han muerto revolucionarios, ¡viva la revolución!"}

La idea de la revolución entendida en términos de guerra no puede desvincularse de la creencia sostenida por el PRT-ERP en la necesidad de generación del denominado "hombre nuevo", proveniente de las ideas de Ernesto "Che" Guevara. Ambas cuestiones combinaban un extremo voluntarismo y un gran subjetivismo. ${ }^{33}$ Como sugieren diversos estudios, las ideas relativas a la modificación de la sociedad siempre se han articulado con las del nacimiento de un nuevo sujeto. Esto supone entender que, la figura del hombre nuevo no nació con las izquierdas revolucionarias latinoamericanas, sino que tiene una larga tradición que atraviesa los diversos pensamientos revolucionarios modernos, desde la revolución francesa, aunque también se la ha relacionado con la tradición cristiana. ${ }^{34}$ Finalmente, en el pensamiento guevarista, corriente a la que adhería el PRT-ERP, el guerrillero heroico era la prefiguración del hombre nuevo. Vera Carnovale ha estudiado el sistema de creencias que organizaba los discursos del PRT-ERP, para destacar que se componía de una visión heroica de la política revolucionaria, una idea sacrificial, ascética, voluntarista y disciplinaria de la militancia, la legitimidad de la violencia y la lucha armada como camino a la transformación social, la primacía de un paradigma de la guerra y cierta confianza en la idea de cambiar al hombre. ${ }^{35}$

La guerrilla comenzó a tener muertos en sus filas muy tempranamente. Una de las formas de honrar a esos muertos caídos en combate fueron los obituarios aparecidos en la prensa, que no sólo los honraban convirtiéndolos en héroes y mártires de la revolución, sino que también los exhibían como modelos a seguir. Las fotografías que acompañan los obituarios son imágenes extraídas de documentos de identidad, en las que sólo vemos los rostros de los militantes caídos. A diferencia de la serie de los cuerpos armados, estas notas no exhiben las figuras de unos soldados sino las de unas personas comunes y corrientes, de unos ciudadanos. En contraste, es el texto escrito el que nos indica que estos muertos son héroes de la lucha armada, que han arriesgado y perdido sus vidas por la revolución. Por ejemplo, en el recuadro: "Han muerto revolucionarios, ¡VIVA LA REVOLUCION!" (Imagen 3), se rinde homenaje a cuatro militantes.
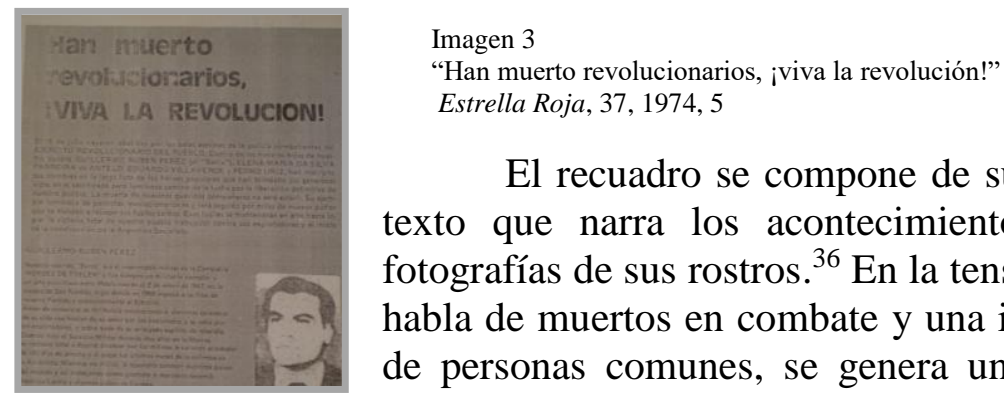

El recuadro se compone de sus nombres y apellidos, un texto que narra los acontecimientos de sus muertes y las fotografías de sus rostros. ${ }^{36}$ En la tensión entre una escritura que habla de muertos en combate y una imagen que exhibe cuerpos de personas comunes, se genera una desmilitarización de los

\footnotetext{
${ }^{33}$ Para un interesante análisis de la figura del hombre nuevo y de los rasgos que éste implicaba se puede consultar el trabajo de Ana Longoni, "La pasión según Eduardo favario. La militancia revolucionaria como ética del sacrificio", El Rodaballo, 1/12, Buenos Aires, 2000.

${ }^{34}$ Vezzetti, Hugo, Sobre la violencia revolucionaria. Memorias y olvidos, Buenos Aires, Siglo XXI, 2009. Principalmente el capítulo 4, "El hombre nuevo", 173-202.

35 Vera Carnovale, Los combatientes. Historia del PRT-ERP, Buenos Aires, Siglo XXI, 2011.

${ }^{36}$ ERP, "Han muerto revolucionarios, ¡VIVA LA REVOLUCION!”, Estrella Roja, 37, agosto de 1974.
} 
militantes. Por medio de la sustracción de la apariencia de guerrilleros, los recuadros conducen a percibir a los combatientes revolucionarios como ciudadanos. Lo que también permite realizar el razonamiento inverso: una persona común puede ser un guerrillero. Cualquier ciudadano podría ser un militante revolucionario y un héroe. "DE CADA CIUDADANO UN COMBATIENTE", afirma una frase citada recurrentemente en la prensa. ${ }^{37}$

Los obituarios también producen una personalización de los muertos que los desplaza hacia una posición de heroicidad. Cada una de las necrológicas es acompañada de la fotografía, el nombre y el apellido del combatiente caído. El muerto es individualizado, nombrado y construido como un héroe. ¿Cómo interpretar esta insistencia en la exhibición de muertes con nombre y apellido?

En su análisis sobre las muertes acontecidas el 11 de septiembre de 2001 en los Estados Unidos tras el ataque a las torres gemelas, Judith Butler sostiene que los obituarios como género discursivo son un instrumento para la distribución pública del duelo y para la constitución de la nación porque enuncian qué vidas vale la pena recordar con dolor, cuáles merecen un duelo, cuáles son las vidas que importan. ${ }^{38} \mathrm{~A}$ su modo, las necrológicas del PRT-ERP marcan cuáles son los muertos que deben entrar al panteón de mártires revolucionarios: nombrándolos, listándolos, enumerándolos, exhibiéndolos y narrando sus vidas. Las muertes de los guerrilleros no son vidas para recordar con dolor -pareciera que no hay tiempo siquiera para hacer un duelo- sino vidas a ser imitadas, modelos subjetivos a seguir. La muerte se instaura, así, como un tópico imposible de ser sorteado por el revolucionario.

El modo en que los obituarios conformaron modelos heroicos a seguir se expone de modo paradigmático en una nota publicada a un año de la "Masacre de Trelew". ${ }^{39}$ En el artículo se narran a modo de homenaje las necrológicas de los dieciséis asesinados en 1972, haciendo foco sobre las formas de vida y de muerte de esos combatientes. El texto despliega diversas estrategias discursivas como formas de persuadir a los destinatarios para que se incorporen a la causa revolucionaria del PRT-ERP (Imagen 4). En los párrafos introductorios se cita una frase del Che Guevara.

Simplemente queremos más bien recordar a nuestros héroes tal como ellos eran en los últimos, febriles días de preparación de la fuga de Rawson. Creemos que esa imagen, a la que la memoria puede añadir una pincelada aquí o allá, los pinta de cuerpo entero tal como ellos habían llegado a ser al final de su trayectoria de revolucionarios, cuando sin saberlo estaban a un paso de reunirse finalmente con

\footnotetext{
${ }^{37}$ ERP, Estrella Roja, 19, 1973, 4.

${ }^{38}$ Butler, Judith, "Violencia, duelo, política", en Vida precaria. El poder del duelo y la violencia, Buenos Aires, Paidós, 2006, 45-78.

${ }^{39}$ En el penal de máxima seguridad de Rawson, donde se encontraban detenidos varios de los principales dirigentes guerrilleros, las organizaciones armadas Montoneros, ERP y FAR coordinaron un plan de fuga. El 15 de agosto de 1972 luego de tomar el penal, un supuesto malentendido de quienes debían pasar a buscar a los prisioneros hizo que sólo pudieran escapar los 6 máximos dirigentes. Otros 19 presos pudieron huir pero llegaron al aeropuerto de Trelew cuando el avión que debía sacarlos ya había partido. Estos militantes fueron trasladados a la base Almirante Zar y allí, luego de varios días de ser torturados, el 22 de agosto fueron fusilados. Tres de ellos se salvaron, aunque luego del golpe militar de 1976 fueron desaparecidos. María Seoane, Todo o nada, Buenos Aires, 2003, 155-190.
} 
su destino americano, porque "en una revolución, cuando es verdadera, se triunfa o se muere. ${ }^{40}$

Imagen 4

"Gloria a los héroes de Trelew"

Estrella Roja, 23, 1973, tapa

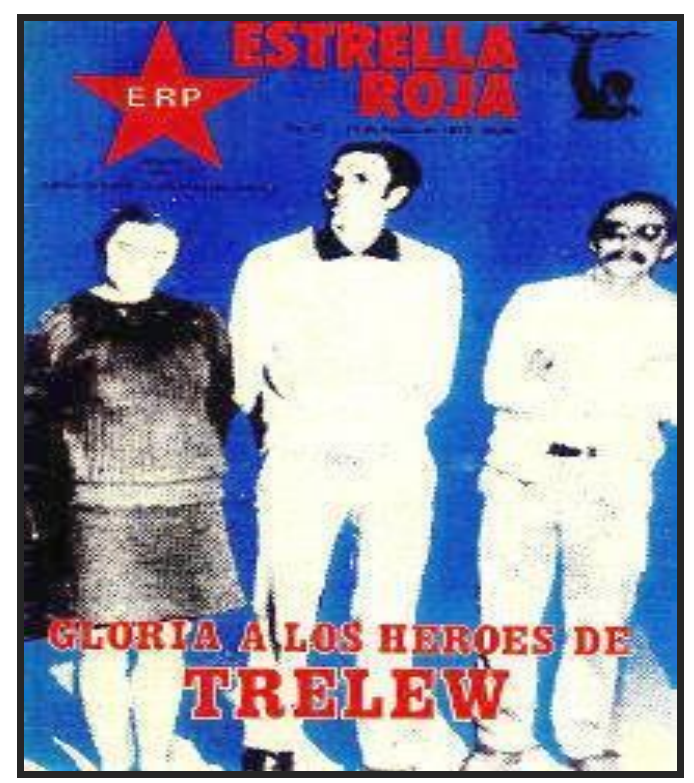

La frase de Guevara funciona como cita de autoridad que no requiere indicar la fuente porque se trata de un "ausente supremo". Las palabras del Che Guevara funcionan como un enunciado de tipo fundador que es compartido por el colectivo y le otorga identidad. ${ }^{41}$ La vida y la muerte del Che se exhiben como modelos ideales a seguir, son el devenir de todo verdadero revolucionario. La mayoría de los relatos de los caídos en Trelew culminan con la narración de la llegada de su muerte. La particularidad de estos cierres del relato es que, como lo había anticipado la referencia al Che en el comienzo del artículo, la llegada de la muerte se presenta como la consecuencia lógica del relato de vida anterior: la muerte es el destino fijado para un revolucionario.

Siempre adelante hasta llegar al destino militante que la estaba aguardando: las balas que partían de las metralletas de los asesinos, las balas de los Infantes de Marina. ${ }^{42}$

Asimiló profundamente sus estudios y reflexiones en los largos años de cárcel y cuando las balas asesinas troncharon a su vida había llegado también su plena madurez moral y política, había alcanzado la estatura de los grandes cuadros revolucionarios que nuestra revolución necesita. Por eso ocupaba uno de los

\footnotetext{
${ }^{40}$ ERP, "22 de agosto. Día del combatiente revolucionario", Estrella Roja, 23, 15 de agosto de 1973. 15.

${ }^{41}$ Maingueneau, Dominique, Nuevas tendencias en análisis del discurso, Buenos Aires, Hachette, 1987.

${ }^{42}$ ERP, "22 de agosto. Día del combatiente revolucionario", op. cit., 17
} 
primeros puestos en la lista. Por eso murió primero, porque era uno de los mejores. ${ }^{43}$

La evaluación final es que la muerte debía acontecer: han muerto quienes habían sido los mejores. Empero, otra lectura puede esbozarse. El acto de morir pareciera ser el que les otorga, a posteriori, el rango de héroes revolucionarios. Si se atiende al nivel argumentativo del texto, se puede observar el funcionamiento de varios topoi que sostienen la argumentación y construyen esa figura tan cara al PRT-ERP que fue la del hombre nuevo, adjudicándole las características de proletario, militar, humilde, sencillo. ${ }^{44}$ Estos lugares comunes se condensan en una idea aglutinante, que le otorga sentido al texto en su totalidad que puede representarse mediante la frase citada del Che Guevara: "En una revolución, cuando es verdadera, se triunfa o se muere". Dos son las modalidades posibles de adquirir heroicidad, triunfando o con la muerte. En suma: cuanto más cerca de la muerte, más heroico, y por lo tanto, más revolucionario.

En síntesis, cuando la prensa presenta los cuerpos de los militantes asesinados hace varias operaciones. Primero, desmilitariza a los guerrilleros al borrar sus caracteres de combate y asimilarlos con personas comunes; segundo, convierte a los militantes caídos en héroes, al compararlos con la figura y el destino del Che Guevara; finalmente, conforma la idea de que cualquiera - esos ciudadanos comunes y corrientes- puede convertirse en un héroe y en un mártir.

\section{El cuerpo femenino: las mujeres en la revolución}

En cuanto al análisis de las figuras corporales presentes en la prensa, se puede afirmar que, si bien hay -aunque escasa- presencia de imágenes de mujeres entre las figuraciones corporales, los cuerpos del combatiente y del héroe, que hemos descripto hasta aquí, son figuras que portan los rasgos tradicionalmente asociados a la masculinidad y la virilidad. El cuerpo armado con sus características de combate, su vestimenta de soldado, sus gestos firmes, su portación de armas, su disponibilidad para la acción y su puño en alto. El cuerpo muerto de los obituarios, contracara del cuerpo armado, ausencia del soldado que ha sido sustraído y que no obstante revalida su presencia bajo las figuras del héroe y el mártir.

Hay escasa presencia de imágenes de cuerpos con rasgos femeninos y son también pocos los artículos que se refieren a las mujeres. Quizás esas imágenes y textos hayan comenzado a ganar presencia a medida que se intentaba que las mujeres se incorporaban a la militancia. ${ }^{45}$ La presencia cada vez más extendida de mujeres colocó a la diferencia

\footnotetext{
${ }^{43}$ Ibid., p. 21. Los destacados me pertenecen.

44 Ducrot, Oswald, “Argumentación y 'topoi’ argumentativo”, Lenguaje en contexto, 1: 1/2, Puebla, 1988. Para Ducrot, la fuerza argumentativa de un enunciado se halla en el conjunto de lugares comunes que se le puede aplicar para extraer conclusiones en el discurso, al escoger una frase sobre otra, el enunciador explota ciertos topoi frente a otros.

${ }^{45}$ La mayoría de las mujeres se incorporó a partir de 1972, año de crecimiento de todas las organizaciones armadas. Pozzi, op. cit. 73. La cantidad de mujeres que integró el PRT-ERP se habría acercado al 30\% o $40 \%$ en el año 1975. Solo dos llegaron a formar parte del Comité Central: Susana Gaggero y Liliana Delfino. Y otras pocas parecen haber sido delegadas en los Congresos del partido. Martínez, op. cit. 117.
} 
sexual en el centro de la escena política. Evidencia de esta presencia de mujeres es la aparición en 1972 de un documento como "Moral y proletarización" que intentaba organizar las relaciones sexuales y morales al interior de la militancia. ${ }^{46} \mathrm{Y}$ también los diversos boletines internos que refieren a la necesidad de realizar acciones para convocar a las mujeres obreras a las filas del partido, como la edición de un folleto que las convoque y la conformación de un Frente de Mujeres. Como ha remarcado Oberti, a pesar de reiterarse en diversos boletines ninguna de estas acciones fue concretada. La importancia de la incorporación de las mujeres radicaba más en la influencia que tenían sobre la familia (es decir sobre los militantes varones y los jóvenes) que en su propia participación. Sin embargo, para los discursos de la agrupación, esa influencia era un arma de doble filo. Muchos de los boletines destacaban que esas mujeres eran también quienes podían, por ser el sector políticamente más atrasado, boicotear la política revolucionaria. ${ }^{47}$

Estos datos sirven para enmarcar la poca presencia de imágenes y artículos con cuerpos femeninos en la prensa partidaria. Respecto de las imágenes se observa que los cuerpos descriptos hasta aquí cancelan al cuerpo femenino. Las mujeres no aparecen, sino que permanecen ocultas e innombrables bajo la neutralidad universal de figuras masculinas. La que está ausente -o más bien neutralizada y no pensada- es la diferencia sexual: el cuerpo femenino es anulado bajo la supuesta neutralidad de las categorías de combatiente y militante.

En cuanto a los artículos escritos, sugiero que existen tres formas en que las mujeres aparecen en ellos: como destinatarias, como tema o como enunciadoras. ${ }^{48}$ Como intentaré mostrar a continuación, sólo cuando son enunciadoras de discursos las mujeres logran desplazarse de los lugares más tradicionales asociadas a los cuerpos, para poder en cambio nombrarse a sí mismas de formas novedosas. Observemos el caso de una carta que tiene a una mujer militante como destinataria. La borradura de las mujeres bajo la forma del universal neutro del varón encuentra su expresión en un homenaje realizado a una mujer militante asesinada. La página presenta dos necrológicas, una de un varón y otra de una mujer. El obituario dedicado al varón se encuentra escrito en tercera persona y contiene varios fragmentos que describen sus aptitudes políticas y militares: empuje, sencillez, dinamismo, iniciativa, humildad. En cambio, el recuadro dedicado a la mujer está escrito en primera persona y tiene una fuerte marca de destinación: es una carta escrita por "Un compañero" para Clara:

\footnotetext{
${ }^{46}$ Ortolani, Luis, “Moral y proletarización”, Políticas de la Memoria, 5, Buenos Aires, [1972]2004/5. El texto fue originalmente publicado con el seudónimo Julio Parra en La gaviota blindada, 0, Rawson.

${ }^{47}$ Oberti, op. cit., 73-86

${ }^{48}$ Para trabajar la situación de enunciación me baso en las elaboraciones de Dominique Maingueneau, quien sostiene que toda situación de enunciación se compone de tres posiciones fundamentales: el enunciador, el coenunciador y la no-persona. El enunciador es el origen de las coordenadas deícticas, en tanto que el coenunciador constituye el tú del enunciado, su destinatario. Entre el enunciador y el co-enunciador existe una relación de alteridad y de diferencia pero que se mantiene en un mismo plano. Finalmente, la no-persona es una entidad que se presenta como no susceptible de asumir un acto de enunciación. La no-persona no se encuentra en el mismo nivel que el enunciador, sino que presenta una relación de ruptura con el mismo. Es importante aclarar que la situación de enunciación no se refiere al contexto empírico en el que el texto se produce, sino que debe ser rastreada en el propio texto. Maingueneau, op. cit.
} 


\begin{abstract}
Querida Clara:
Es tan difícil despedirte, tan difícil poner en papel todo lo que se siente por la desaparición de un compañero como vos, con tu calidad humana. Creo que a nadie le ha quedado tan a la medida el seudónimo "CLARA" todas tus cosas eran claras, tu vida, tus definiciones, tu forma de amar, tus alegrías, tu presencia en la guerra, tu ejemplo, todo tan claro como tus hermosos ojos verdes que, aunque endurecidos por el combate y la militancia, se permitían razonables treguas de ternura, cada vez que alguna de tus hijas se miraba en ellos. (...) Fuiste un ejemplo de hombre nuevo, de mujer revolucionaria, porque tú entrega no tuvo límites. ${ }^{49}$
\end{abstract}

Es interesante ver los modos en que la carta dedicada a Clara la nombra. Ella no sólo es una "mujer revolucionaria", sino también "un compañero" y un "ejemplo de hombre nuevo". Clara encarna ante los ojos del enunciador masculino, una figura extraña: entre hombre y mujer. El discurso partidario parece no encontrar la forma de nombrarla en femenino. Porque la idea de hombre nuevo sólo puede enunciarse y construirse en masculino. No hay derivación femenina para esa figura. Por eso el texto titubea cuando debe nombrar a la Clara revolucionaria. En contraste, el texto es muy preciso cuando se trata de enunciar sus atributos esencialmente femeninos: su belleza, su ternura, su maternidad. ${ }^{50}$

¿Qué implica que en el discurso del PRT-ERP la mujer militante sea nombrada como hombre nuevo? La filósofa feminista Adriana Cavarero sostiene que el "yo" del discurso y de la filosofía implica a un sujeto neutro universal, que no es ni hombre ni mujer, sería un sujeto de sexo masculino que se asume a sí mismo como universal. Esta cancelación de la diferencia sexual es el signo de un no reconocimiento. Supone que la diferencia es registrada pero no pensada como fundamental para el sujeto. Según esta autora este proceso lógico de cancelación de la diferencia sexual conduce a la producción de un sujeto masculino-neutro, encarnación del universal. ${ }^{51}$

En las figuraciones del cuerpo en la prensa del PRT-ERP hay cierto registro de la diferencia sexual, pero no así un reconocimiento de la centralidad de esa diferencia en la constitución del sujeto revolucionario. La equivalencia de los cuerpos $($ mujer $=$ varón $=$ hombre nuevo), rehúye la posibilidad de pensar e imaginar la diferencia sexual y no hace otra cosa que cancelar al cuerpo femenino o, como veremos en lo que sigue, parcelarlo en algunas tareas y espacios subordinados y secundarios. Esta neutralización de lo femenino es a su manera una forma de construir la diferencia sexual, otorgando ciertos rasgos a "los hombres" y a "las mujeres", dándole voz solamente a uno de los términos de esa diferencia.

Las mujeres aparecieron también como el tema de algunos artículos. En esos casos no aparecían como las destinatarias de los textos, sino que su posición era la de ser habladas por el partido, mientras que ellas presentaban la figura de la no-persona del

\footnotetext{
${ }^{49}$ Estrella roja, 68, 1976, 7. Destacado mío.

${ }^{50}$ El PRT-ERP representó recurrentemente a la guerrillera a partir de rasgos como la belleza, acercándola de esa forma a la figura de la ninfa. A través de dichos rasgos típicamente asociados a lo femenino se las definía y unificaba como un particular en relación con el universal masculino que instauraba el partido. Oberti, op. cit. 94-95.

${ }^{51}$ Adriana Cavarero, "Para una teoría de la diferencia sexual”, Debate feminista, 6:12, México, 1995.
} 
enunciado. Esta posición se puede observar en el artículo "El papel de la mujer en la revolución”. El artículo se despliega en dos páginas centrales y comienza con un epígrafe de Fidel Castro "Cuando se discute acerca de los derechos de las mujeres, vemos que no puede haber derecho de la mujer en nuestra América, ni derechos de niños, ni derechos de madres, ni derechos de esposas si no hay Revolución ". ${ }^{52}$ Esta referencia equipara mujer, madre, esposa y niños. La nota continúa con un diagnóstico de la situación de las mujeres: a causa de la doble explotación de la que son víctimas en el capitalismo se han convertido en el "sector más atrasado" de la sociedad. Estarían, desde esta lógica, menos preparadas cultural y políticamente por encontrarse relegadas a las actividades del hogar y por ello es que poseen una menor participación que los varones en las actividades revolucionarias.

Luego de nombrarlas como "atrasadas", la nota sostiene la necesidad de buscar nuevas formas organizativas para que, a pesar de sus limitaciones, las mujeres se incorporen a las tareas de la revolución. Se las quiere convocar por sus posibilidades de influir sobre sus maridos obreros. El artículo presenta una lista de las tareas que ellas pueden realizar, son tareas "pequeñas" pero "igualmente indispensables a la revolución":

Tareas manuales, costura de uniformes, banderas, insignias, "berretines". Formación y cuidado de archivos, de materiales, cuidado y limpieza de armas, fichajes de objetivos militares, coberturas. Alojamiento de compañeros, casas para reuniones. Comunicaciones, correos, transporte de mensajes y materiales, compra de implementos necesarios a la guerra y a la propaganda, tareas de logística, tareas de sanidad, distribución de materiales. Visita y aprovisionamiento a los compañeros presos. ${ }^{53}$

Las tareas mencionadas lejos están de evidenciar cambios respecto de las realizadas tradicionalmente por las mujeres en el capitalismo. En los términos de este artículo, la emancipación femenina sólo se circunscribiría a la realización de tareas de madre y de esposa. Aquello que no aparece enunciado es el vínculo propio de las mujeres con la política. Esta imposibilidad quizás sea el resultado de otra gran ausencia, la de las mujeres como enunciadoras. Es un texto que trata sobre las mujeres en la revolución pero que posee un enunciador masculino. Las mujeres son habladas por otros.

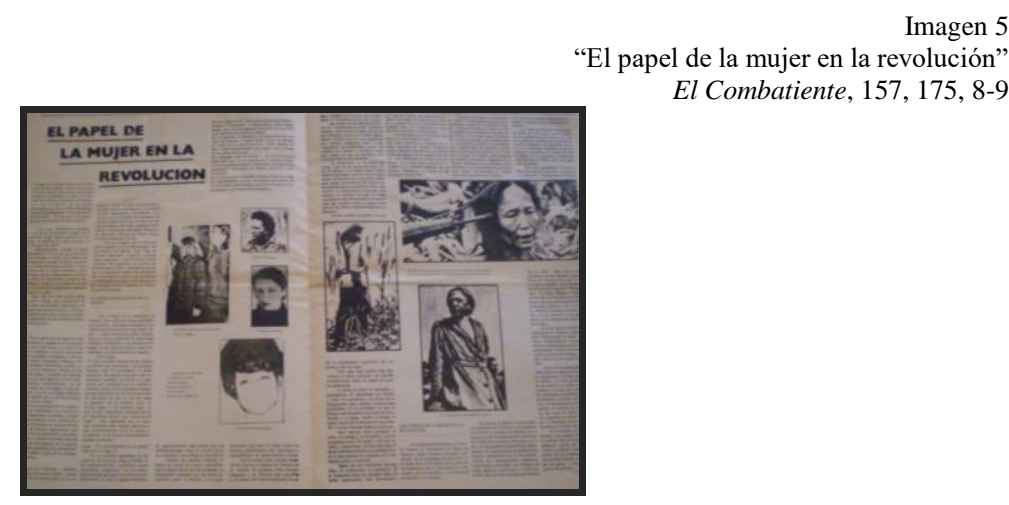

\footnotetext{
${ }^{52}$ PRT, “El papel de la mujer en la revolución”, El combatiente, 157, 1975, 8.

${ }^{53}$ Ibid., 15
} 
Las imágenes de la nota refuerzan lo escrito (Imagen 5). Un primer grupo se compone de fotografías de mujeres militantes argentinas asesinadas. Un segundo grupo corresponde a mujeres con armas de otras revoluciones, rusa y vietnamita, las muestran capturadas, sacrificadas y en estado de peligro. Un tercer grupo se compone de una mujer amamantando a un niño y de un grupo de mujeres cocinando un guiso popular.

Las ausentes son las imágenes de las mujeres del PRT-ERP, las que permaneciendo aún con vida realizan tareas de militancia. Los ausentes son los cuerpos femeninos valientes o realizando alguna hazaña o proeza. Algo pareciera tensionarse cuando se unen un cuerpo femenino y un arma, como si no hubiese espacio discursivo para mostrar ese lazo. Quizás esa imposibilidad hace que se recurra a la incorporación de imágenes de mujeres de otras revoluciones. Cuando se trató de mostrar cuerpos femeninos, la prensa reforzó los estereotipos tradicionales sobre las mujeres y sus papeles a cumplir. Actividades de crianza, de cuidado, de apoyo. Cocinar. Lavar. Tareas de madre y esposa. Y ausencia de heroicidad cuando ellas están cerca de un arma.

En tercer lugar, se encuentran aquellos artículos en los cuales las mujeres aparecen como enunciadoras de discursos. Se trata de madres que les escriben a sus hijos guerrilleros, de mujeres que les escriben cartas a varones militantes para darles contención o a modo de despedida cuando han muerto. ${ }^{54}$ Los casos que me interesa analizar aquí son el de la despedida de una madre a su hija militante y el de una carta que les escribe una militante desde la Compañía de Monte en Tucumán a sus familiares. En estos dos textos se observan desplazamientos en los modos de nombrarse y caracterizar a las mujeres militantes. La imposibilidad de nombrar a las guerrilleras en femenino que se observaba en los artículos en los que el enunciador era masculino, se revierte en estos casos, cuando son las propias mujeres quienes se nombran a sí mismas.

En "Despedida a mi hija", se observa una diferencia en la forma en que esta madre nombra a su hija con respecto a aquellos obituarios dedicados a las militantes mujeres, que contenían enunciadores masculinos y que se organizaban sobre cierta imposibilidad de nombrar a las guerrilleras en femenino. El desplazamiento de un enunciador masculino hacia uno femenino parece ser la explicación de esta apertura que se muestra en la carta de la madre que, por otra parte, reflexiona justamente en su escritura sobre los modos de nombrar a la hija ("rescato para vos los otros calificativos..."): subversiva, guerrillera, revolucionaria.

Quiero rescatar para vos hija querida y admirada y respetada los otros calificativos, el de subversiva, porque es verdad que intentaste subvertir el orden impuesto por la corrupción y la explotación de un régimen que nunca fue democrático. Rescato para vos mi tierna y querida el calificativo de guerrillera porque está quedando demostrado que esto que han hecho como a la chica de Panne, a la familia Pujadas y a otros muchos, avala tu método. (...) Y te nombro también como revolucionaria porque yo me pregunto, si no es sólo siendo una revolucionaria se puede oponerse a un sistema que

\footnotetext{
${ }^{54}$ Se trata de ERP, "Carta de una empleada pública a la compañía de monte", Estrella roja, 66, 1975. ERP, "Carta de la madre de un combatiente a su hijo", Estrella Roja, 45, 1974, 5; ERP, "El adiós al compañero", Estrella Roja, 57, 1975, 4.
} 
hambrea, explota y tortura. Te entierro hijita querida subversiva, guerrillera $\mathrm{y}$ revolucionaria y te pido con toda modestia perdón por mi cobardía. ${ }^{55}$

Nominaciones novedosas aparecían también en "La vida en el monte. Carta de una compañera a sus padres". ${ }^{56}$ Ese artículo muestra a las mujeres en posiciones descentradas, generando fisuras respecto de las representaciones clásicas. Enunciado desde la posición de una mujer guerrillera, el texto habilitó posiciones más igualitarias para las mujeres y las mostró cargando mochilas, combatiendo, dirigiendo grupos. ${ }^{57}$ En efecto, acompaña a esta carta una imagen de la guerrillera del PRT-ERP en el Monte (Imagen 6), recortada de otra fotografía que circuló en la prensa y que mostraba al ejército del monte en su conjunto, entre un grupo de varios varones, se vislumbraba a esta compañera, que sólo se distinguía en su feminidad, por el pelo largo y los rasgos de su rostro.
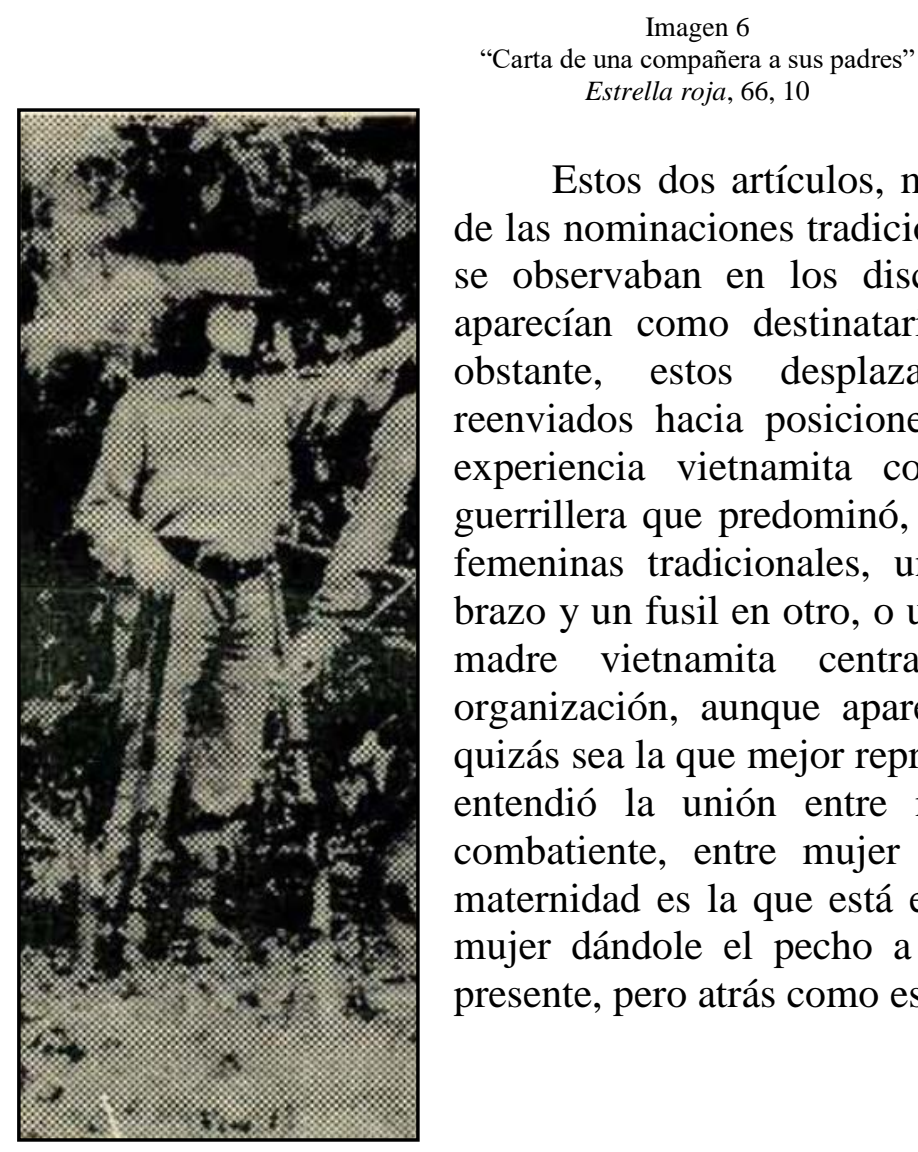

Estos dos artículos, muestran una diferencia respecto de las nominaciones tradicionales de la mujer militante, que se observaban en los discursos en los que las mujeres aparecían como destinatarias o tema del enunciado. No obstante, estos desplazamientos fueron rápidamente reenviados hacia posiciones más clásicas. Tomando a la experiencia vietnamita como modelo, la figura de la guerrillera que predominó, la cubría con las características femeninas tradicionales, una madre, con un niño en un brazo y un fusil en otro, o una mujer bella. La imagen de la madre vietnamita central en el imaginario de la organización, aunque apareció pocas veces en la prensa, quizás sea la que mejor representa el modo en que el partido entendió la unión entre mujer y arma, entre mujer y combatiente, entre mujer y política. En esa imagen la maternidad es la que está en primer plano, se trata de una mujer dándole el pecho a su niño. El fusil también está presente, pero atrás como escondido (Imagen 7).

\footnotetext{
${ }^{55}$ ERP, "Despedida a mi hija", Estrella roja, 72, 1976, 13.

${ }^{56}$ ERP, "La vida en el monte. Carta de una compañera a sus padres”, Estrella roja, 66, 1975, 9.

${ }^{57}$ Oberti, op. cit., 94. La autora realiza un interesante análisis sobre la aparición de las mujeres en este artículo y otros referidos a la Compañía de Monte.
} 


\section{A modo de cierre}

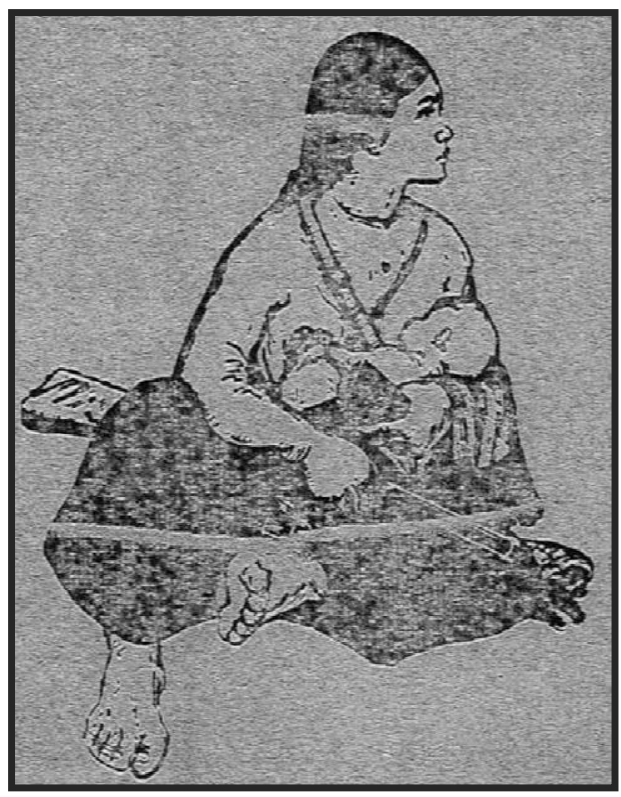

Me propuse indagar en las figuraciones corporales en la prensa del PRT-ERP en la Argentina de los años setenta. Me interesaba aportar a la comprensión del modo en que la diferencia sexual se constituyó en un eje mediante el que se distinguían los cuerpos que requería el proyecto de revolución que el partido intentaba llevar adelante. Con esa idea, analicé imágenes y artículos referidos a los cuerpos de los militantes, destacando varias cuestiones sobre las que recapitularé a modo de cierre.

$$
\begin{gathered}
\text { Imagen } 7 \\
\text { "Por qué luchamos" Estrella Roja, 2, 1971, } 8
\end{gathered}
$$

La prensa del PRT-ERP mostró cierta confianza en la plasticidad de los cuerpos para los fines de la revolución, plasticidad que se exhibía cuando se proponían adecuar los cuerpos de los ciudadanos para convertirse en combatientes. Los cuerpos del combatiente y del héroe se asociaban con rasgos corporales tradicionalmente asociados a la masculinidad. Así, las figuras corporales articularon una división sexual y jerarquizada de la militancia. Por un lado, unos cuerpos masculinos que realizaban las tareas principales de la política, donde las figuras fundamentales fueron las del combatiente y del héroe que se presentaban cargadas de los rasgos tradicionales de la masculinidad. Por otro lado, los cuerpos femeninos aparecieron en contadas ocasiones. Cuando las mujeres guerrilleras aparecieron, al discurso partidario le costó articular modos de nombrarlas en femenino, necesitó desplazarse hacia la figura masculina. En esos casos el discurso exhibió una pobreza conceptual, que le impidió designar a las mujeres en femenino. Esta elisión fue la consecuencia de que la figura del hombre nuevo -central en el imaginario del PRT-ERPsólo fuera nombrada en masculino, no poseía una derivación femenina.

No obstante, el discurso sí hallaba formas de nombrar a las mujeres cuando se trataba de atributos tradicionalmente femeninos como la belleza, la ternura, la maternidad y el cuidado. De esa forma, las imágenes presentes en la prensa reenviaban a las mujeres hacia roles específicamente femeninos y les demandaban la realización de actividades secundarias: la crianza de los hijos, el cuidado de la familia, el apoyo a sus maridos. En ese contexto discursivo, se comprende la primacía de la figura de la madre vietnamita, que no hacía otra cosa que exaltar la maternidad. Fueron escasos los casos en que el discurso partidario pudo imaginar otras actividades para las mujeres y otros modos de nombrarlas. Esos desplazamientos se hicieron posibles cuando quienes aparecían como enunciadoras de los discursos fueron las propias mujeres. Los sesenta fueron años de cambios culturales en las familias, en las relaciones de pareja y en la crianza de los hijos. En ese marco, los discursos del PRT-ERP dejaron intactas, la mayoría de las veces, las posiciones 
tradicionales femeninas y les propusieron a las mujeres colocar su saber de cuidado al servicio de la revolución. Esos discursos intentaban reubicar a las mujeres en los roles que, dado el marco de transformaciones sociales y culturales, ya estaban siendo abandonados también en otros ámbitos. Quizás hayan sido intentos -problemáticos, por cierto- de acomodar a quienes en sus prácticas se estaban desubicando.

Pero quizás -y esta es la hipótesis que me ha guiado en este trabajo- este reenvío no haya sido más que el efecto del funcionamiento paradojal de la política revolucionaria. Paradoja derivada de persistir en ciertos modos de comprender, imaginar y actuar la política. De ciertos modos de pensar a los sujetos de dicha revolución. Una noción estrecha de la revolución, que permaneció enmarcada dentro de ciertos límites y que les impidió concebir nuevas formas de relación entre el género, los cuerpos y la política.

\section{Bibliografía}

Andújar, Andrea, D’Antonio, Débora, Gil Lozano, Fernanda, Gramático, Karin, y Rosa, María Laura(comp.), De minifaldas, militancias y revoluciones. Exploraciones sobre los 70 en Argentina, Buenos Aires, Luxemburg, 2009.

Badiou, Alain, El siglo, Buenos Aires, Manantial, 2005, 20.

Barrancos, Dora, Mujeres en la sociedad argentina. Una historia de cinco siglos, Buenos Aires, Sudamericana, 2007

Butler, Judith, "Hablando claro, contestando. El feminismo crítico de Joan Scott", Rey desnudo, II:4, Buenos Aires, 2014

Butler, Judith, "Violencia, duelo, política", en Vida precaria. El poder del duelo y la violencia, Buenos Aires, Paidós, 2006, 45-78.

Calveiro, Pilar, Política y/o violencia. Una aproximación a la guerrilla de los años 70, Buenos Aires, Norma, 2005.

Carnovale, Vera, Los combatientes: historia del PRT-ERP, Buenos Aires, Siglo XXI, 2011.

Cavarero, Adriana, "Para una teoría de la diferencia sexual", Debate feminista, 6: 12, México, 1995.

Ciollaro, Noemí, Pájaros sin luz. Testimonios de mujeres de desaparecidos, Buenos Aires, Planeta, 2000.

Chartier, Roger, El mundo como representación. Estudios sobre historia cultural, Barcelona, Gedisa, 2005.

Cosse, Isabella "Militancia, sexualidad y erotismo en la izquierda armada de los años 70", en Dora Barrancos, Donna Guy, Adriana Valobra, (ed.), Moralidades y comportamientos sexuales: Argentina, 1880-2011, Buenos Aires, Biblos, 2014.

Cosse, Isabella, "Infidelidades: moral, revolución y sexualidad en las organizaciones de la izquierda armada en la Argentina de los años 70", Prácticas de oficio, 1: 19, Sna Miguel, 2017.

Cosse, Isabella; Felitti, Karina y Manzano, Valeria (ed.), Los '60 de otra manera. Vida cotidiana, género y sexualidades en la Argentina, Buenos Aires, Prometeo, 2010.

Cosse, Isabella, Pareja, sexualidad y familia en los años sesenta. Una revolución discreta en Buenos Aires, Buenos Aires, Siglo XXI, 2010.

Diana, Marta, Mujeres guerrilleras. La militancia de los setenta en el testimonio de sus protagonistas femeninas, Buenos Aires, Planeta, 1996.

Domenach, Jean-Marie, La propaganda política, Buenos Aires, Eudeba, 1993.

Ducrot, Oswald, "Argumentación y 'topoi' argumentativo", Lenguaje en contexto, 1:1/2, Puebla, 1988. 
Feijoó, María del Carmen y Nari, Marcela, "Women in Argentina during the 1960s", Latin American Perspectives, 23:1, California, 1996.

Felitti, Karina: La revolución de la píldora. Sexualidad y política en los sesenta, Buenos Aires, Edhasa, 2012.

Grammático, Karin, Mujeres montoneras. Una historia de la Agrupación Evita, 1973-1974, Buenos Aires, Luxemburg, 2011.

Longoni, Ana, "La pasión según Eduardo favario. La militancia revolucionaria como ética del sacrificio", El Rodaballo, 11/12, Buenos Aires, 2000.

Maingueneau, Dominique, Nuevas tendencias en análisis del discurso, Buenos Aires, Hachette, 1987.

Martínez, Paola, Género, política y revolución en los años setenta. Las mujeres del PRT-ERP, Buenos Aires, Imago Mundi, 2009.

Nari, Marcela, "Abrir los ojos, abrir la cabeza: el feminismo en la Argentina de los años '70", Feminaria, IX:18/19, Buenos Aires, 1998.

Oberti, Alejandra, Las revolucionarias, Buenos Aires, Edhasa, 2015.

Pedro, Joana Maria, Scheibe Wolff, Cristina, y Veiga, Ana María (org.), Resistências, gênero e feminismos contra as ditaduras no cone sul, Florianópolis, Ed. Mulheres, 2011.

Peller, Mariela, Vida cotidiana, familia y revolución: la militancia en el PRT-ERP en la Argentina de los años sesenta y setenta, Tesis de Doctorado, Buenos Aires, Universidad de Buenos Aires, 2013.

Peller, Mariela, "Vida cotidiana y militancia armada en los años "70 en la Argentina: problemas conceptuales e hipótesis de lectura", INTERthesis, 10: 1, Santa Catarina, 2013.

Pittaluga, Roberto, "Nociones de la revolución en el PRT-ERP”, ponencia presentada en las VIII Jornadas Interescuelas/Departamentos de Historia, Salta, Universidad Nacional de Salta, 2001.

Pozzi, Pablo, 'Por las sendas argentinas...' El PRT-ERP, la guerrilla marxista, Buenos Aires, Imago Mundi, 2004.

Pucciarelli, Alfredo (Ed.), La primacía de la política. Lanusse, Perón y la Nueva Izquierda en tiempos del GAN, Buenos Aires, Eudeba, 1999.

Robles Recabarren, Javiera, "Memorias de la clandestinidad: Relatos de la militancia femenina del Frente Patriótico Manuel Rodríguez", Revista Nomadías, 19, Snatiago de Chile, 2015.

Schmucler, Héctor, "Testimonio de los sobrevivientes", Controversia, 9-10, México, 1980.

Scott, Joan Wallach, "El género: Una categoría útil para el análisis histórico", en María Celia Cangiano y Lindsay Dubois, De mujer a Género, teoría, interpretación y práctica feminista en las ciencias sociales, Buenos Aires, CEAL, 1996.

Scott, Joan Wallach, “Género: ¿Todavía una categoría útil para el análisis?”, La manzana de la discordia, Cali, 2011

Scott, Joan Wallach, Género e historia, México, Fondo de Cultura Económica, 2008

Scott, Joan Wallach, Las mujeres y los derechos del hombre, Buenos Aires, Siglo XXI, 2012.

Tortti, María Cristina, "Protesta social y "Nueva Izquierda" en la Argentina del "Gran Acuerdo Nacional", en Pozzi, Pablo y Schneider, Alejandro (comp.), Los setentistas. Izquierda y clase obrera: 1969- 1976, Buenos Aires, Eudeba, 2002.

Vezzetti, Hugo, Sobre la violencia revolucionaria. Memorias y olvidos, Buenos Aires, Siglo XXI, 2009.

Vidaurrázaga, Tamara, "La escisión entre lo individual y lo colectivo en la moral revolucionaria militante de la nueva izquierda", Revista Sujeto, Subjetividad y Cultura, 4, Santiago de Chile, 2012.

Weisz, Eduardo, El PRT-ERP: Nueva Izquierda e izquierda Tradicional, Buenos Aires, Ediciones del Instituto Movilizador de Fondos Cooperativos, 2004 